\title{
Marie Scarpa, Les poissons rouges sont-ils solubles dans le réalisme?
}

\section{Paola Paissa}

\section{(2) OpenEdition}

10 Journals

\section{Édition électronique}

URL : https://journals.openedition.org/studifrancesi/39703

DOI : 10.4000/studifrancesi.39703

ISSN : 2421-5856

Éditeur

Rosenberg \& Sellier

\section{Édition imprimée}

Date de publication : 1 décembre 2004

Pagination : 405

ISSN : 0039-2944

\section{Référence électronique}

Paola Paissa, « Marie Scarpa, Les poissons rouges sont-ils solubles dans le réalisme? », Studi Francesi [En ligne], 143 (XLVIII | II) | 2004, mis en ligne le 30 novembre 2015, consulté le 19 mai 2021. URL : http:// journals.openedition.org/studifrancesi/39703 ; DOI : https://doi.org/10.4000/studifrancesi.39703

Ce document a été généré automatiquement le 19 mai 2021.

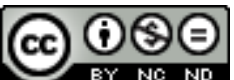

Studi Francesi è distribuita con Licenza Creative Commons Attribuzione - Non commerciale - Non opere derivate 4.0 Internazionale. 


\title{
Marie Scarpa, Les poissons rouges sont-ils solubles dans le réalisme?
}

\author{
Paola Paissa
}




\section{RÉFÉRENCE}

MARIE SCARPA, Les poissons rouges sont-ils solubles dans le réalisme?, «Poétique», 133, février 2003, pp. 64-72.

1 Après avoir brièvement discuté de la fonction du «détail» dans l'écriture zolienne (simple «effet de réel» ou plutôt «excès de réel», dévoilant l'impossibilité d'atteindre l'exhaustivité de la mimesis?), Marie Scarpa s'attache à donner une interprétation «ethnocritique» du détail de «l'aquarium aux poissons rouges» situé à la fin du célèbre passage descriptif de l'étalage de la charcuterie dans Le Ventre de Paris.

2 Partant du constat que Le Ventre de Paris représente «la réappropriation zolienne du motif tant folklorique qu'artistique du combat de Carnaval et de Carême» (pp. 67), thèse que l'auteure développe largement dans le vaste ouvrage consacré à ce roman (Le Carnaval des Halles. Une ethnocritique du Ventre de Paris de Zola, Paris, CNRS éditions, 2000, pp. 304), Marie Scarpa considère l'aquarium aux poissons rouges comme un opérateur à la fois descriptif et diégétique.

3 En tant qu'opérateur descriptif, il participe de la description «esthétisante» qui fait de l'étalage des charcutiers une «nature morte», dont les poissons qui nagent «continuellement» constituent la clôture, avec l'irruption du vivant, bien que prisonnier.

4 En tant qu'opérateur diégétique, cet élément est inscrit dans le texte comme un indice préfigurant le destin de Florent: «Roi des Maigres» dans le règne des «Gras» et figure christique à la face de Carême, le parcours de l'ex-forçat Florent, depuis Cayenne jusqu'au Pavillon de la Marée, est en fait entièrement mis sous le signe du poisson. 